\title{
Synthetic Strategies Towards the Synthesis of Oxyisocyclointegrin
}

\author{
Robert J. Smith, ${ }^{*}$ Bill C. Hawkins*
}

\begin{abstract}
Numerous natural products containing oxepine-fused flavones have been isolated and reported over the last fifty years. This compound class typically possess anti-proliferative and/or antibacterial properties. Herein we provide a full account of our original synthetic strategies along with further details of our ultimately successful approach to oxyisocyclointegrin.
\end{abstract}

\section{Introduction}

Natural products continue to be a great platform for showcasing new synthetic methods as well as providing a supply of medicinally relevant molecules. The Moraceae plant family are a rich source of bioactive molecules, some of which are oxepinefused flavones (Figure 1). Neocyclomurosin $(1)^{[1]}$ is a well-studied antibacterial, while artoindonesianin E1 (2) ${ }^{[2]}$ and carpelastofuran $(3)^{[3]}$ have been shown to possess activity against leukemia and breast cancer cells, respectively. Despite the known biological activity of these closely related structures, isocycloheterophylin (4) and oxyisocyclointegrin (5) have received little attention. ${ }^{[4]}$ In addition, surprisingly, there are a limited number of methods to forge the fused-oxepine ring described in the literature. To the best of our knowledge only two distinct strategies to access this substrate have been reported, namely an oxidative intramolecular cyclization strategy (transition metals, ${ }^{[5]} \mathrm{DDQ}^{[6]}$ and photochemically mediated ${ }^{[7]}$ ) and most recently, a Mitsunobu reaction. ${ }^{8]}$ Given that several structurally similar substrates possess significant biological activity, we deemed the synthesis of oxyisocyclointegrin a worthy pursuit. Recently, we reported the successful 11-step synthesis of oxyisocyclointegrin. ${ }^{[9]}$ Herein we describe some of the failed strategies and the various challenges faced en route to completing the synthesis of oxyisocyclointegrin (5).

R. J. Smith, Dr. B. C. Hawkins

Department of Chemistry

University of Otago

Dunedin, New Zealand

rismithchemistry@outlook.com

bhawkins@chemistry.otago.ac.nz

https://blogs.otago.ac.nz/hawkinsgroup/

Supporting information for this article is given via a link at the end of the document.((Please delete this text if not appropriate))

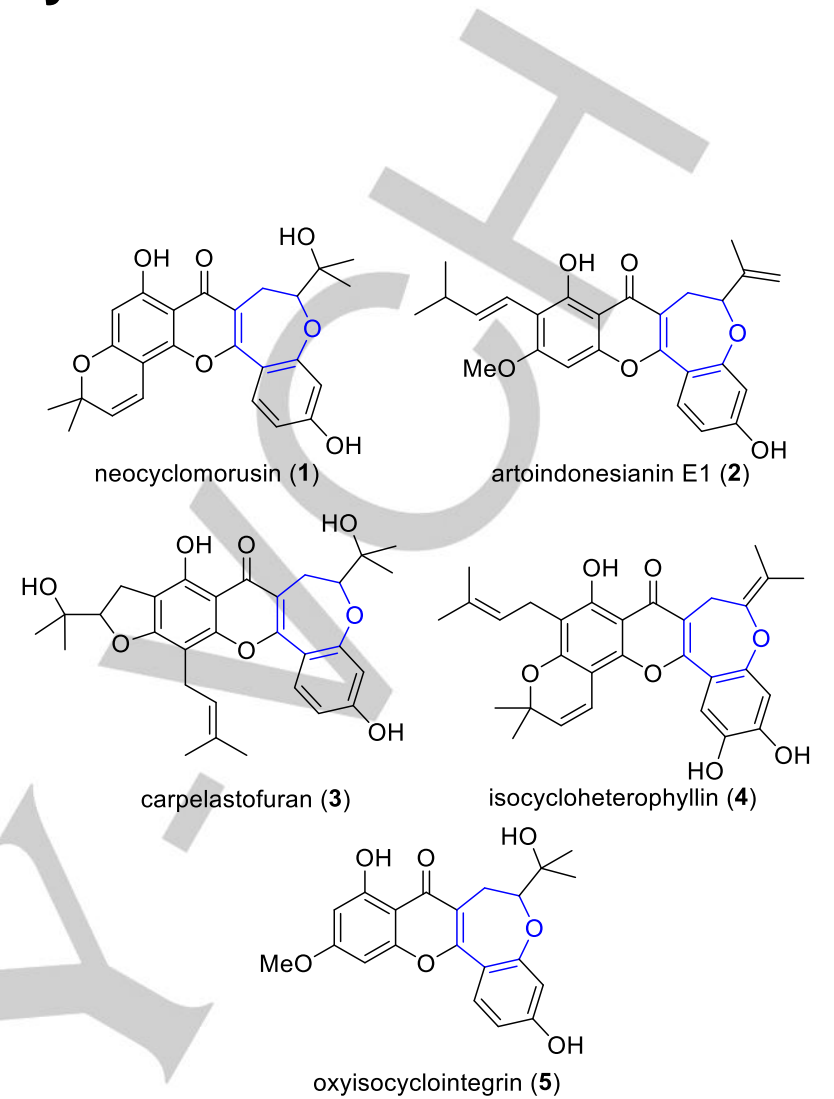

Figure 1. Oxepine-fused flavones isolated from the moraceae family of plants.

\section{Results and Discussion}

Our first retrosynthetic analysis of oxyisocyclointegrin involved installation of the pendant tertiary alcohol late in the synthesis due to its suspected propensity to undergo dehydration (Scheme 1). This transformation, in a forward synthetic sense, was anticipated to be achieved through the addition of a suitable organometallic reagent to the methyl ketone $\mathbf{6}$. Compound $\mathbf{6}$ would in turn be accessed via a Wacker oxidation of the vinyl group in oxepine 7 . The oxepine ring should be accessible via an intramolecular Mitsunobu reaction of flavone $\mathbf{8}$. The synthesis of the flavone itself could be achievable using our recently reported method to access flavones from 1,1-diacyl-2-vinylcyclopropanes. ${ }^{[10]}$ 
<smiles>C=CC=Cc1cc(O)cc2c1Oc1cc(OC)ccc1-c1c-2oc2cc(OC)ccc2c1=O</smiles><smiles>C=CC(O)Cc1c(-c2ccc(O)cc2[18OH])oc2cc(OC)cc(O)c2c1=O</smiles><smiles>C=C</smiles><smiles>COc1cc(O)c(C(C)=O)c(O)c1</smiles><smiles>COC(=O)c1ccc(O)cc1O</smiles>

10

provide the Markovnikov product, the methyl ketone. However, when a heteroatom is in the allylic or homoallylic position the product distribution can change. It has been hypothesized that this is due to coordination of the heteroatom to the palladium centre. ${ }^{[12]}$ This concept has been utilized to direct Wacker oxidation to preferentially form the aldehyde. However, there are also systems with heteroatom substituents that give solely the methyl ketone or a mixture of products under the classical reaction conditions. Additionally, there have been reports that subtle changes in the reaction conditions, such as the amount and type of copper salt or the concentration of chloride anions, can change the stereochemistry of the nucleopalladation reaction. As such, it can be difficult to predict the regiochemical outcome of the Tsuji-Wacker reaction. Several reports in the literature have utilised modified Tsuji-Wacker reaction conditions to selectively oxidise substrates with Lewis-basic substituents to form the ketone product. ${ }^{[13]}$ Application of these procedures to this model system had mixed success (Table 1). Changing the salt additive from copper chloride to copper acetate improved the ratio of $1: 6$ to 1:3 (entries 1-2), whereas, an alternate procedure using DessMartin periodinane as the oxidant provided the ketone in a 1:2 ratio (entry 3 ).

Table 1. Optimization of the Tsjui-Wacker oxidation reaction.

Scheme 1. Retrosynthetic analysis of oxyisocyclointegrin (5).

In order to rapidly assess the viability of this approach, the model oxepine-fused flavone $\mathbf{1 2}$ was constructed from commercially available 2-hydroxyacetophenone using our previously disclosed procedure (Scheme 2). ${ }^{[8]}$<smiles>C=CC(O)Cc1c(-c2ccccc2O)oc2ccccc2c1=O</smiles>

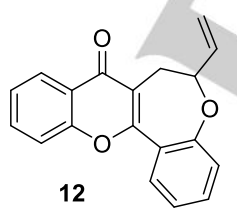

Scheme 2. Intramolecular Mitsunobu reaction forges the oxepine-fused flavone core.

With the model flavone-oxepine in hand, the potential of the vinyl handle to undergo the proposed Wacker oxidation was investigated. In the first instance, standard Tsuji-Wacker reaction conditions were employed (Table 1, entry 1). ${ }^{[11]}$ This afforded a mixture of the ketone 13 and aldehyde 14 in 1:6 ratio, respectively, as determined by analysis of the ${ }^{1} \mathrm{H}$ NMR spectrum of the reaction mixture. The crude residue was subjected to column chromatography, to provide the less polar and minor isomer, ketone 13. Further elution provided the undesired aldehyde 14 as the major product. The mechanism of the Tsuji-Wacker oxidation is generally accepted to have three main steps; coordination of alkene to the palladium centre, followed by nucleopalladation and a $\beta$-hydride elimination. The stereochemical outcome of the nucleopalladation step determines the products that are formed. Typically, the nucleopalladation proceeds in an anti-fashion to

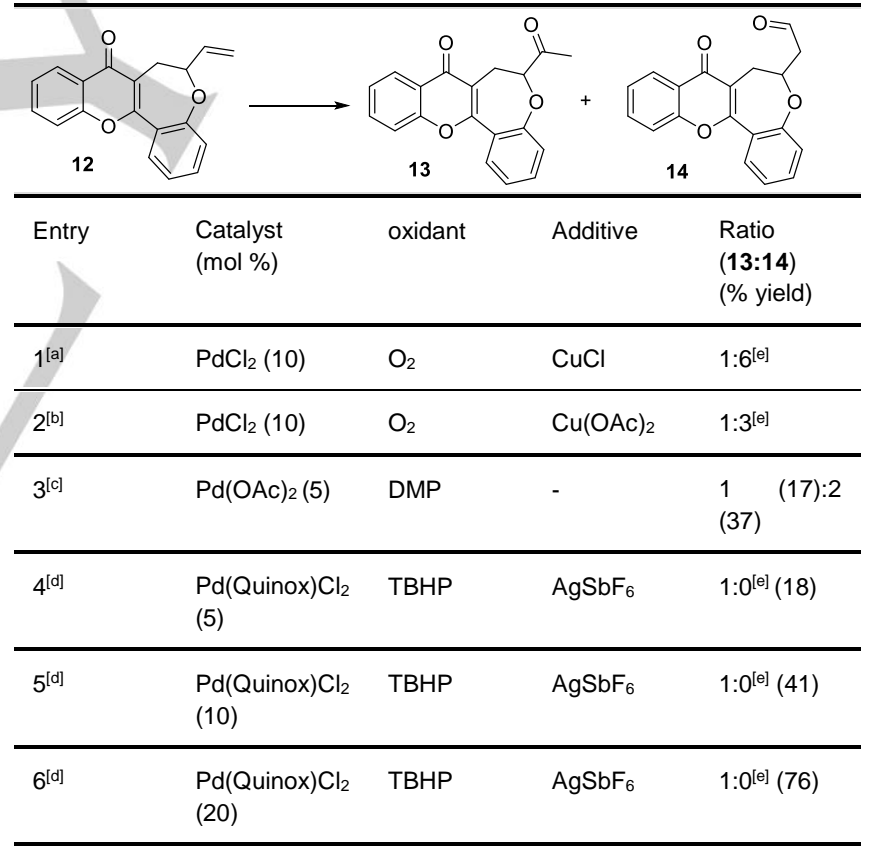

[a] reaction performed in 7:1 DMF: $\mathrm{H}_{2} \mathrm{O}$ at $60^{\circ} \mathrm{C}$ overnight. [b] reaction performed in 7:1 DMA: $\mathrm{H}_{2} \mathrm{O}$ at $60{ }^{\circ} \mathrm{C}$. [c] reaction performed in $7: 1$ $\mathrm{CH}_{3} \mathrm{CN}: \mathrm{H}_{2} \mathrm{O}$ at $60{ }^{\circ} \mathrm{C}$ overnight. [d] reaction performed in DCM at room temperature overnight. [e] determined by integration of ${ }^{1} \mathrm{H} N M R$ of crude material. DMP = Dess-Martin periodinane, $\mathrm{TBHP}=$ tert-butyl hydroperoxide.

Recently, there has been efforts to develop ligand-controlled Tsuji-Wacker processes to make the reaction more reliable, especially with classically challenging substrates. ${ }^{[14]}$ One such method utilises $\mathrm{Pd}[\mathrm{Quinox}] \mathrm{Cl}_{2}$ with tert-butyl hydroperoxide 
(TBHP) as the oxidant and generally provides complete selectivity for the methyl ketone product of allyl ether substrates. ${ }^{[14 a]}$ Pleasingly, application of this procedure provided complete selectivity for the methyl ketone (entry 4), however high catalyst loading (20 mol\%) was required to ensure complete conversion (entry 6).

Given the success of the key Mitsunobu and Wacker reactions, along with the rich literature describing the additions of alkyl lithium species to structurally similar molecules, attention was turned to the preparation of the substrate required for the synthesis of oxyisocyclointegrin (5).

To prepare 1,3-diketones with highly substituted and electron rich aromatic rings, like 17, the literature predominantly reports the use of a Baker-Venkataraman rearrangement. This reaction typically provides modest yields of the 1,3-diketone, ${ }^{[15]}$ however, it also affords a free phenol functionality. As a result, chemoselectivity issues surrounding the cyclopropanation would be expected, and hence an alternative procedure was required to provide access to the requisite 1,3-diketone.

Initial attempts to access the 1,3-diketone $\mathbf{1 7}$ focused on using standard Claisen condensation chemistry (Scheme 3). Specifically, the allyl ether $\mathbf{1 5}$ was treated with a strong base in the presence of the methyl benzoate 16a. Unfortunately, no traces of the corresponding 1,3-diketone was detected. Direct addition of the presumed acetophenone anion of $\mathbf{1 5}$ to the acid chloride 16b was attempted; however, this was also unsuccessful.

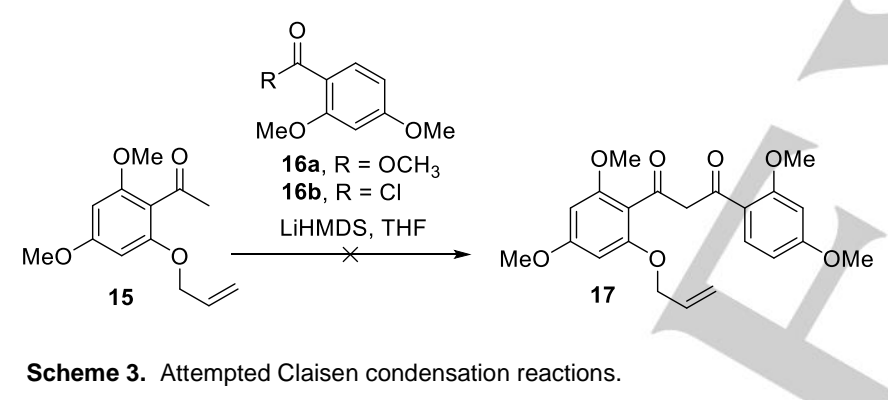

A proposed alternative route to the desired 1,3-diketone 17 was acylation of the $\beta$-ketoester 18 , followed by hydrolysis and decarboxylation. To this end, acetophenone derivative 15 was engaged in a Claisen condensation with diethylcarbonate to provide the $\beta$-ketoester 18 (Scheme 4). This was then treated with sodium hydride and benzoyl chloride to provide the $\beta$-diketoester 19. Efforts to decarboxylate 19 under basic conditions resulted in a retro-Aldol reaction to provide the $\beta$-ketoester 18 . Under acidic reaction conditions 19 underwent a retro-Aldol and decarboxylation to return the starting acetophenone derivative 15 was obtained. Attempts at thermal extrusion were also unsuccessful. The failure of traditional hard enolization methods to synthesize the desired 1,3-diketone necessitated the exploration of methods that were unlikely to be affected by the electron rich nature of the aromatic rings. Therefore, a Lewis acidmediated (soft, reversible) enolization reaction was attempted (Scheme 5). ${ }^{[16]}$

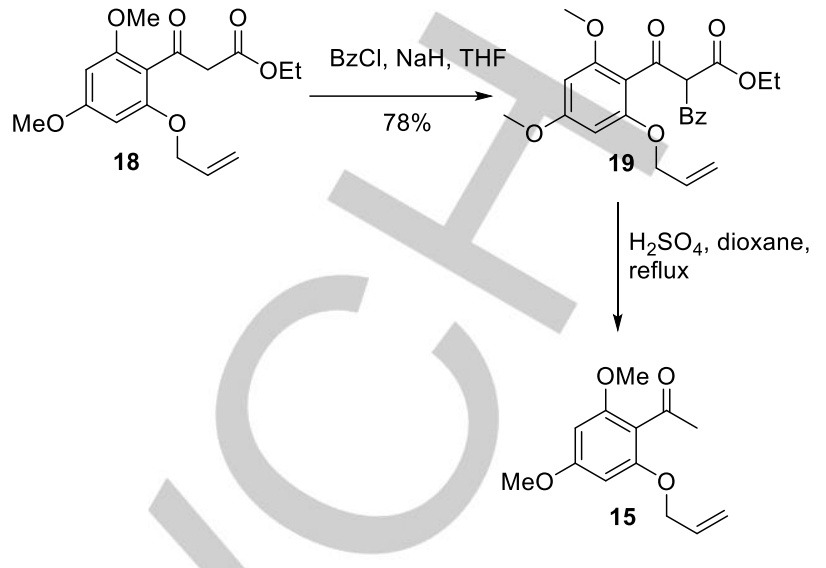

Scheme 4. Attempted decarboxylation of 19.

Treatment of the acetophenone $\mathbf{1 5}$ with benzotriazole $\mathbf{2 0}$ in the presence of $\mathrm{MgBr}_{2} . \mathrm{Et}_{2} \mathrm{O}$ and $\mathrm{N}, \mathrm{N}$-diisopropylethylamine (DIPEA) smoothly provided the 1,3-diketone 17 in moderate yield $(65 \%$, $82 \%$ brsm). Synthesis of the cyclopropane 21 from the 1,3diketone 17 under the standard cyclopropanation conditions provided poor conversion to the cyclopropane. Improved results were achieved by changing the solvent to methanol and heating the reaction to reflux (Scheme 5). Treatment of the vinyl cyclopropane $\mathbf{2 1}$, to the established flavone forming reaction conditions, both as the crude product and after purification by column chromatography produced an intractable mixture of products.
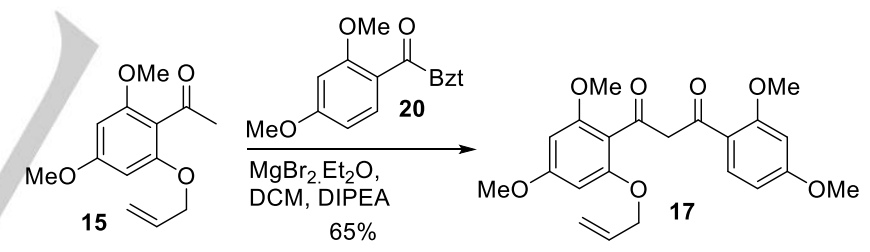
trans-1,4-dibromo-2-butene
$\mathrm{K}_{2} \mathrm{CO}_{3}, \mathrm{MeOH}$

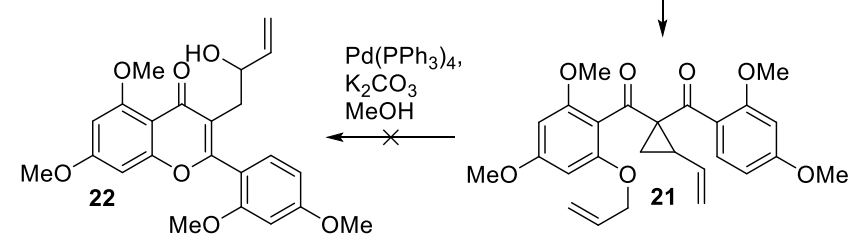

Scheme 5. Synthesis of the 1,3-diketone 17 and its vinyl cyclopropyl analog 21.

The unfortunate failure of the flavone formation from the vinyl cyclopropane 21 necessitated a new strategy to access oxyisocyclointegrin (5). As in the original strategy, installation of the tertiary alcohol would be performed late in the synthesis, this 
time through a decarboxylative halogenation of $\mathbf{2 3}$ and nucleophilic substitution reaction. ${ }^{17}$ The key disconnection in this new strategy was the cyclisation to the oxepine by an oxa-Michael reaction (Scheme 6). The $\alpha$ - $\beta$-unsaturated ester 24 could be accessed by cross metathesis of the 3-allylflavone 25 .<smiles>[R]Oc1ccc2c(c1)OC(C(C)(C)C([O])=O)Cc1c-2oc2cc(OC)cc(O[R])c2c1=O</smiles><smiles>[R]Oc1ccc(-c2c(C/C=C/C(=O)O)c(=O)c3c(OC)cc(OC)cc3oc2=O)c(O)c1</smiles><smiles>c1ccccc1</smiles><smiles>[R]Oc1ccc(C(=O)CC(=O)c2ccc(O[R])c(OCCC)c2OCC=C)c(O[R])c1</smiles>

Scheme 6. Revised retrosynthesis of oxyisocyclointegrin (5).

Synthesis of this intermediate flavone required the formation of a mono- $\alpha$-allyl-1,3-diketone, which could be difficult to access through classical nucleophilic substitution methods due to the potential for over allylation of the a-carbon. Recent work conducted in our laboratory led to the discovery of an intramolecular Tsuji-Trost-type allyl migration, which exclusively provides mono- $\alpha$-allyl-1,3-diketones in good yields. ${ }^{[18]}$ To test the validity of this approach a model system was constructed (Scheme 7). The 1,3-diketone 28 was synthesized in high yield from 2-allyloxyacetophenone and methyl-2-methoxybenzoate. The Tsuji-Trost allyl migration, ${ }^{[18]}$ and subsequent acid promoted cyclization provided the flavone 29 in $18 \%$ yield over 2 steps (Scheme 7). Treatment of 29 with $\mathrm{BBr}_{3}$ produced the desired phenol $\mathbf{3 0}$ in $79 \%$ yield. This substrate was not particularly amenable to the cross-metathesis reaction, with incomplete conversion of starting material. Subsequent treatment of $\mathbf{3 3}$ with sodium acetate in refluxing methanol provided the oxepine in an $88 \%$ yield. Due to the low yield of the cross metathesis it was decided to protect the phenol $\mathbf{3 0}$ as an acetate. The acetate $\mathbf{3 1}$ was prepared in excellent yield upon treatment of phenol $\mathbf{3 0}$ with acetic anhydride in pyridine. The acetate $\mathbf{3 1}$ smoothly underwent cross metathesis with methyl acrylate to provide the unsaturated ester 34. Following this, $\mathbf{3 4}$ was directly converted to the oxepine 35 by treatment with sodium acetate in methanol at reflux.

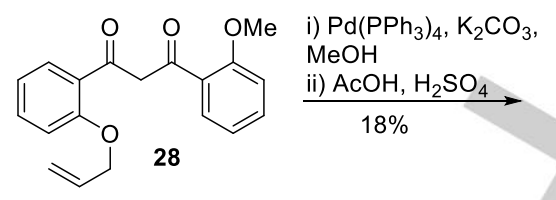<smiles>C=CCc1c(-c2ccccc2OC)oc2ccccc2c1=O</smiles><smiles>[R]Oc1ccccc1-c1oc2ccccc2c(=O)c1C/C=C/C(=O)OC</smiles>

33, $R=H, 22 \%$
$34, R=A c, 77 \%$ PhOH, DCM, reflux

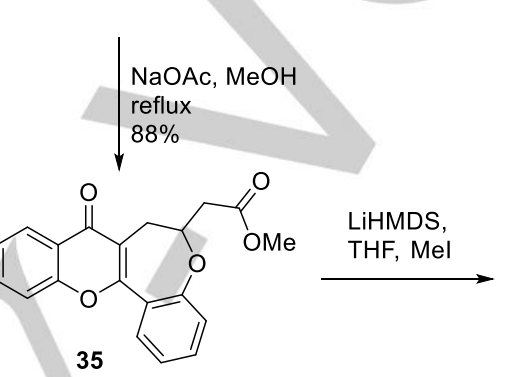<smiles>COC(=O)/C=C/Cc1c(-c2ccccc2O)oc2ccccc2c1=O</smiles>

Scheme 7. Oxa-Michael addition to forge the oxepine core.

Efforts to install the geminal dimethyl groups $\alpha$ - to the ester, were ultimately unsuccessful. Treatment of $\mathbf{3 5}$ with LiHMDS followed by methyl iodide, resulted in an undesired retro-Michael addition, whilst treatment of $\mathbf{3 5}$ with LDA followed by methyl iodide provided complex mixtures. Given the observed propensity of the oxepine to open under standard alkylation conditions this route was abandoned.

A third approach to oxyisocyclointegrin (5) was devised, whereby the desired tertiary alcohol and oxepine ring would be constructed through nucleophilic attack onto the corresponding epoxide 36 (Scheme 8). Notably, this method should allow for the stereoselective synthesis of oxyisocyclointegrin and other structurally related natural products, as there are numerous methods for stereoselective epoxidation reactions. ${ }^{[19]}$<smiles>[R6]Oc1cc([R7])ccc1-c1oc2cc(OC)cc(O[R])c2c(=O)c1CC1(C)OC1(C)C=C</smiles><smiles>[R]Oc1ccc(-c2oc3cc(OC)cc(O[R])c3c(=O)c2CC=C)c(O[R])c1</smiles><smiles>[R]Oc1cc(OC)cc2oc(-c3ccc([R20])cc3[R])c(CC=C(C)C)c(=O)c12</smiles>

Scheme 8. Revised retrosynthesis of oxyisocyclointegrin (5). 
This retrosynthetic analysis also proceeded through a 3prenylflavone derivative, which is the natural product integrin $(R$ $=\mathrm{H}, 37) \cdot{ }^{[4 a]}$ The previously prepared 1,3-diketone 17 was treated with tetrakis(triphenylphosphine)palladium $(0)$ and potassium carbonate in methanol to provide the $\alpha$-allyl-1,3-diketone (not shown). Treatment of the intermediate with $10 \%$ sulfuric acid in $\mathrm{AcOH}$ afforded the flavone 39 in a $64 \%$ yield over two steps (Scheme 9). ${ }^{[18]}$

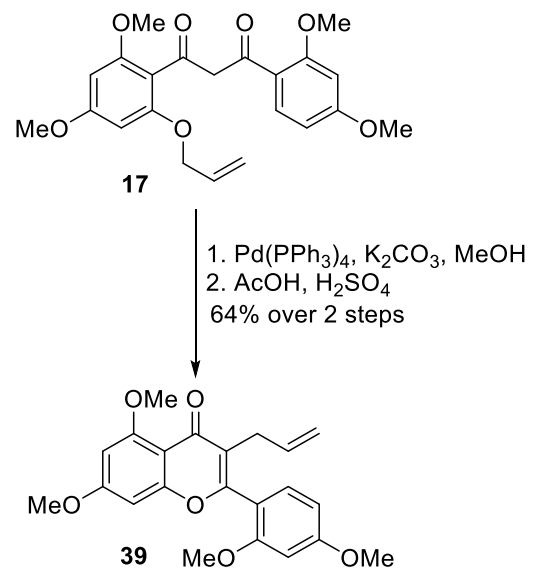

Scheme 9. Tsjui-Trost allyl migration and condensation to form 39.

Treatment of $\mathbf{3 9}$ with $\mathrm{HBr}$ in acetic acid in a sealed tube at reflux provided a mixture of two compounds: namely the trimethoxy $40 \mathrm{a}$, dimethoxy $40 \mathrm{~b}$ along with traces of an inseparable mixture of two monomethoxy oxepines (Scheme 10).

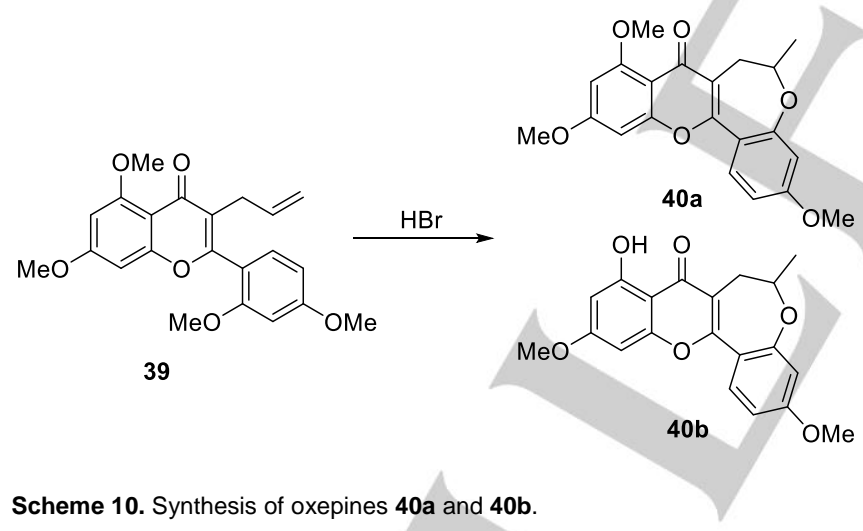

Although this methodology provides rapid access to the oxepine scaffold, multiple products are formed and the methyl oxepine cannot be readily functionalised to the requisite tertiary alcohol. Therefore, it was not a synthetically useful result for the synthesis of oxyisocyclointegrin. Careful addition of three equivalents of boron tribromide to a solution of 39 in DCM allowed for the selective formation of the desired monomethyl ether $\mathbf{4 1}$ in a reasonable yield (Scheme 11). ${ }^{[9]}$

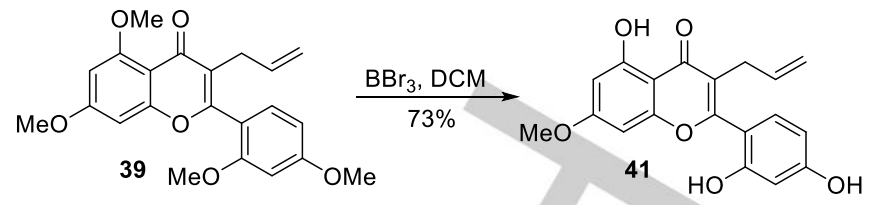

Scheme 11. Selective de-methylation to provide phenol 41.

Treatment of the phenol $\mathbf{4 1}$ with acetic anhydride and pyridine afforded the triacetoxyflavone $\mathbf{4 2}$ in high yield. This was then engaged in a cross-metathesis reaction with 1-methyl-2-butene to provide the prenylflavone $\mathbf{4 4}$, in a modest yield (Scheme 12).

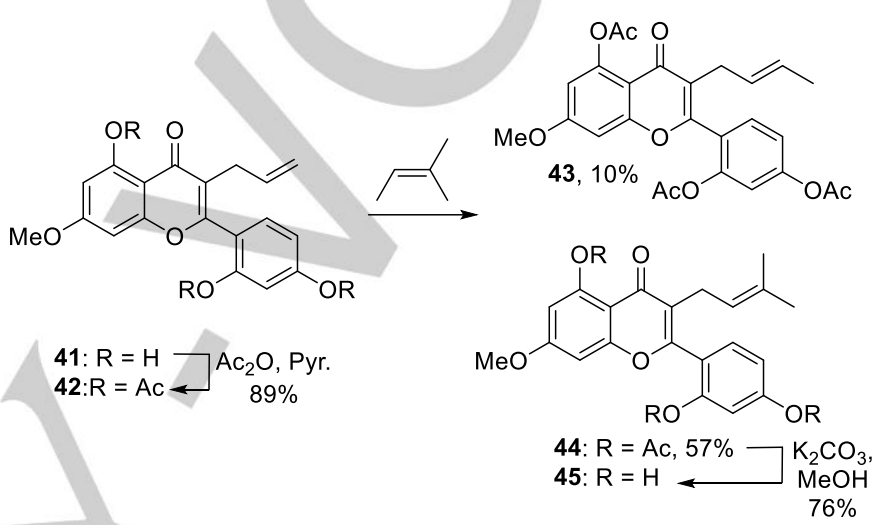

Scheme 12. Synthesis of the 3-prenylated flavone $\mathbf{4 5 .}$

The low yield was due to the formation of the alternate cross metathesis product $\mathbf{4 3}$, isolated as the major component of a mixture of by-products. In an attempt to improve the synthesis of the desired 3-prenylflavone $\mathbf{4 4}$ and avoid the formation of byproducts, difficult to remove by chromatography, an oxidative cleavage/Wittig strategy was explored (see SI).

Oxidative cyclization of $\mathbf{4 5}$ proved to be difficult, with standard procedures (DMDO, $\mathrm{H}_{2} \mathrm{O}_{2}$ and $\mathrm{Pd}$ catalyzed) failing to provide the oxepine. However, a photochemical mediated oxidative cyclization ${ }^{7}$ smoothly forged the oxepine core to provide the tertiary hydroperoxide and desired oxyisocyclointegrin (5) in a 4:1 mixture (Scheme 13). ${ }^{[7]}$ The crude residue was redissolved in methanol and treated with sodium borohydride to reduce the hydroperoxide to the alcohol, providing the desired natural product in $83 \%$ yield over two steps.<smiles>COc1cc(O)c2c(=O)c(CC=C(C)C)c(-c3ccc(O)cc3O)oc2c1</smiles>

Scheme 13. Synthesis of oxyisocyclointegrin (5) 


\section{Conclusions}

Model systems were designed to inform our synthetic work and build chemical understanding of this compound manifold. Initial efforts to utilize our previously disclosed cyclopropane methodology were unsuccessful. Whilst a oxa-Michael addition strategy readily forged the oxepine ring system, attempts to further functionalize the scaffold were hampered by oxepine ringopenings. Acid catalysed de-methylation of flavone 39 was unsuccessful with competing hydrobromination followed by a Friedel-Crafts alkylation hampering efforts towards oxyisocyclointergin (5). Ultimately, a photochemical mediated oxidative cyclization allowed for the first total synthesis of integrin and oxyisocyclointegrin in 9 and 11 steps, respectively.

\section{Experimental Section}

Thin layer chromatography (tlc) was performed on ALUGRAMB aluminium-backed UV254 silica gel $60(0.20 \mathrm{~mm})$ plates. Compounds were visualized with either $\mathrm{p}$-anisaldehyde or $20 \% \mathrm{w} / \mathrm{w}$ phosphomolybdic acid in ethanol. Column chromatography was performed using silica gel 60. Infrared spectra were recorded on a Bruker Optics Alpha ATR FT-IR spectrometer. High resolution mass-spectra (HRMS) were recorded on a Bruker microTOFQ mass spectrometer using an electrospray ionisation (ESI) source in either the positive or negative modes. ${ }^{1} \mathrm{H}$ NMR spectra were recorded at either $400 \mathrm{MHz}$ on a Varian 400-MR NMR system or at $500 \mathrm{MHz}$ on a Varian $500 \mathrm{MHz}$ AR premium shielded spectrometer. All spectra were recorded from samples in $\mathrm{CDCl}_{3}$ at $25^{\circ} \mathrm{C}$ in $5 \mathrm{~mm}$ NMR tubes Chemical shifts are reported relative to the residual chloroform singlet at $\delta$ $7.26 \mathrm{ppm}$. Resonances were assigned as follows: chemical shift (multiplicity, coupling constant(s), number of protons, assigned proton(s)). Multiplicity abbreviations are reported by the conventions: $s$ (singlet), $d$ (doublet), dd (doublet of doublets), ddd (doublet of doublet of doublets), $t$ (triplet), td (triplet of doublets), q (quartet), qd (quartet of doublets), $\mathrm{m}$ (multiplet). Proton decoupled ${ }^{13} \mathrm{C}$ NMR spectra were recorded at either 100 $\mathrm{MHz}$ on a Varian 400-MR NMR system or at $125 \mathrm{MHz}$ on a Varian 500 $\mathrm{MHz}$ AR premium shielded spectrometer under the same conditions as the ${ }^{1} \mathrm{H}$ NMR spectra. Dichloromethane $\left(\mathrm{CH}_{2} \mathrm{Cl}_{2}\right)$, tetrahydrofuran and diethyl ether were dried using a PURE SOLV MD-6 solvent purification system. Melting points were measured on a DigiMelt MPA 161 apparatus. Unless otherwise noted, all experiments were conducted at room temperature.

9 - acetyl - 8,19 - dioxatetracyclo[9.8.0.02,7.013,18]nonadeca $1(11), 2,4,6,13,15,17$ - heptaen - 12 - one (13) and 2 - $\{12$ - oxo $8,19 \quad$ - dioxatetracyclo[9.8.0.02,7.013,18]nonadeca 1(11),2,4,6,13,15,17 - heptaen - 9 - yl\}acetaldehyde (14). Procedure 1: To a solution of silver hexafluoroantimonoate $(25 \mathrm{mg}, 0.007 \mathrm{mmol})$ in DCM $\left(1 \mathrm{~mL}\right.$ ), in the dark, was added $\mathrm{Pd}$ (quinox) $\mathrm{Cl}_{2}$ complex (44 mg, $0.012 \mathrm{mmol}$, $20 \mathrm{~mol} \%$ ) and the reaction mixture was stirred for 15 mins. The reaction mixture was then diluted with $\mathrm{DCM}(4 \mathrm{~mL})$ before $70 \% \operatorname{TBHP}(\mathrm{aq})(0.7 \mathrm{~mL}$, $7.2 \mathrm{mmol}$ ) was added and stirred for an additional 10 minutes before being cooled in an ice bath. Flavone 13 (175 mg, $0.6 \mathrm{mmol})$ in DCM (2 mL) was added with stirring, after 5 minutes the ice bath was removed, and the reaction mixture allowed to warm to room temperature with stirring overnight. The reaction as quenched with saturated aqueous sodium sulphite and diluted with EtOAc $(10 \mathrm{~mL})$. The aqueous layer was separated and back-extracted with EtOAc $(10 \mathrm{~mL})$, and the combined organic extracts were washed with water $(4 \times 10 \mathrm{~mL})$ and brine $(10 \mathrm{~mL})$, dried over magnesium sulfate, filtered and concentrated in vacuo. Silica gel chromatography allowed isolation of the methyl ketone 13 as an oil (138 mg, 76\%). ${ }^{1} \mathrm{H}$ NMR $\left(500 \mathrm{MHz}, \mathrm{CDCl}_{3}\right.$ ), $\delta$ (ppm): 8.24 (dd, $1 \mathrm{H}, \mathrm{J}=7.9,1.6$ $\mathrm{Hz}), 7.90$ (dd, $1 \mathrm{H}, \mathrm{J}=7.8,1.6 \mathrm{~Hz}$ ), 7.69 (ddd, $1 \mathrm{H}, \mathrm{J}=8.4,7.1,1.7 \mathrm{~Hz}$ ), $7.52(\mathrm{~m}, 1 \mathrm{H}), 7.49$ (ddd, $1 \mathrm{H}, \mathrm{J}=9.0,7.3,1.7 \mathrm{~Hz}), 7.42$ (ddd, $1 \mathrm{H}, \mathrm{J}=7.9$, $7.2,1.1 \mathrm{~Hz}$ ), $7.31-7.26(\mathrm{~m}, 2 \mathrm{H}), 5.07(\mathrm{dd}, 1 \mathrm{H}, \mathrm{J}=8.5,4.3 \mathrm{~Hz}), 3.35$ (dd, $1 \mathrm{H}, \mathrm{J}=15.6,4.3 \mathrm{~Hz}$ ), 3.00 (dd, $1 \mathrm{H}, \mathrm{J}=15.6,8.5 \mathrm{~Hz}), 2.33(\mathrm{~s}, 3 \mathrm{H}) .{ }^{13} \mathrm{C}$ NMR (125 MHz, $\left.\mathrm{CDCl}_{3}\right), \delta$ (ppm): 208.0, 179.0, 161.7, 158.8, 158.3, 136.4, 135.3, 131.1, 128.7, 127.8, 127.7, 126.6, 126.0, 125.3, 120.7, 120.3, 94.1, 29.2, 27.3. FTIR (ATR / cm-1): 3068, 2917, 1724, 1614, 1466, 1401, 1370, 756. HRESI-MS calculated for $\mathrm{C}_{19} \mathrm{H}_{14} \mathrm{O}_{4} \mathrm{Na}+[\mathrm{M}+\mathrm{Na}]+: 329.0784$; found: 329.0765. Procedure 2: To a solution of flavone $13(282 \mathrm{mg}, 0.971 \mathrm{mmol})$ in $7: 1 \mathrm{MeCN} / \mathrm{H}_{2} \mathrm{O}(5 \mathrm{~mL})$ was added Dess-Martin periodinane $(500 \mathrm{mg}$, $1.20 \mathrm{mmol})$ and $\mathrm{Pd}(\mathrm{OAc})_{2}(11 \mathrm{mg}, 0.049 \mathrm{mmol})$. The reaction mixture was heated to $50^{\circ} \mathrm{C}$ for 18 hours, then reduced in vacuo and purified by column chromatography (1:4-2:3 EtOAc/40-60 Pet. Ether) to provide the ketone $13(50 \mathrm{mg}, 17 \%)$ as an oil and the aldehyde 14 as a solid. (110 mg, 37\%): ${ }^{1} \mathrm{H}$ NMR $\left(500 \mathrm{MHz}, \mathrm{CDCl}_{3}\right), \delta(\mathrm{ppm}): 9.91(\mathrm{~s}, 1 \mathrm{H}), 8.25$ (dd, $1 \mathrm{H}, \mathrm{J}=8.0$ $1.6 \mathrm{~Hz}$ ), 7.91 (dd, $1 \mathrm{H}, \mathrm{J}=8.0,1.60 \mathrm{~Hz}), 7.70(\mathrm{~m}, 1 \mathrm{H}), 7.54(\mathrm{~m}, 1 \mathrm{H}), 7.48$ $(\mathrm{m}, 1 \mathrm{H}), 7.43(\mathrm{~m}, 1 \mathrm{H}), 1.30(\mathrm{~m}, 1 \mathrm{H}), 7.12(\mathrm{dd}, 1 \mathrm{H}, \mathrm{J}=8.1,0.9 \mathrm{~Hz}), 5.19$ $(\mathrm{m}, 1 \mathrm{H}), 3.10(\mathrm{dd}, 1 \mathrm{H}, \mathrm{J}=15.5,4.2 \mathrm{~Hz}$ ), 2.96 (ddd, $1 \mathrm{H}, \mathrm{J}=16.6,8.8,2.8$ $\mathrm{Hz}), 2.83-2.75$ (m, 2H). ${ }^{13} \mathrm{C}$ NMR (125 MHz, CDCl3), $\delta$ (ppm): 202.3, $179.6,161.8,158.8,158.3,136.4,135.2,131.1,127.8,126.7,126.0,125.3$, 121.0, 120.7, 85.6, 56.1, 51.6, 30.8. FTIR (ATR / cm-1): 3021, 2918, 2822, $2735,1721,1619,756$. HRESI-MS calculated for $\mathrm{C}_{19} \mathrm{H}_{14} \mathrm{O} \mathrm{O}_{4} \mathrm{Na}+[\mathrm{M}+\mathrm{Na}]+$ 329.0784; found: 329.0771 , MP: $175-180^{\circ} \mathrm{C}$.

Ethyl 3 - [2,4 - dimethoxy - 6 - (prop - 2 - en - 1 - yloxy)phenyl] - 3 oxopropanoate (18). To a solution of acetophenone 15 (745 mg, 3.15 $\mathrm{mmol})$ in anhydrous THF $(15 \mathrm{~mL})$ maintained at $0{ }^{\circ} \mathrm{C}$ was added $\mathrm{NaH}(60 \%$ dispersion in mineral oil, $378 \mathrm{mg}, 9.46 \mathrm{mmol}$ ), with stirring for 30 minutes. After this time diethyl carbonate $(0.76 \mathrm{~mL}, 6.31 \mathrm{mmol})$ was added and the reaction heated at reflux overnight. After this time the reaction was cooled to room temperature and poured into a beaker containing $1 \mathrm{M} \mathrm{HCl}$ over ice. This was transferred to a separatory funnel and extracted with EtOAc (x2). The combined organic extracts were washed with water and brine, dried over magnesium sulfate and reduced in vacuo. The crude residue was purified by column chromatography (1:4-2:3 EtOAc:40-60 Pet. Ether) to provide the title compound $(760 \mathrm{mg}, 78 \%)$ as an oil. ${ }^{1} \mathrm{H} \mathrm{NMR}(400 \mathrm{MHz}$ $\left.\mathrm{CDCl}_{3}\right), \delta(\mathrm{ppm}): 6.07$ (d, $\left.1 \mathrm{H}, \mathrm{J}=2.0 \mathrm{~Hz}\right), 6.05(\mathrm{~d}, 1 \mathrm{H}, \mathrm{J}=2.0 \mathrm{~Hz}), 5.97(\mathrm{~m}$, $1 \mathrm{H}), 5.38(\mathrm{dq}, 1 \mathrm{H}, \mathrm{J}=17.3,1.6 \mathrm{~Hz}), 5.24(\mathrm{dq}, 1 \mathrm{H}, \mathrm{J}=10.6,1.4 \mathrm{~Hz}), 4.50$ (dt, $2 \mathrm{H}, \mathrm{J}=5.1,1.6 \mathrm{~Hz}), 4.12(\mathrm{q}, 2 \mathrm{H}, \mathrm{J}=7.2 \mathrm{~Hz}), 3.79(\mathrm{~s}, 2 \mathrm{H}), 3.78(\mathrm{~s}, 3 \mathrm{H})$ $3.76(\mathrm{~s}, 3 \mathrm{H}), 1.19$ (t, 3H, J = 7.2 Hz). ${ }^{13} \mathrm{C} \mathrm{NMR}\left(100 \mathrm{MHz}, \mathrm{CDCl}_{3}\right), \delta(\mathrm{ppm})$ 194.3, 167.6, 163.0, 159.2, 158.1, 132.5, 117.7, 112.2, 91.7, 90.8, 69.4, 60.9, 55.8, 55.4, 51.2, 14.1. FTIR (ATR / cm-1): 2981, 2941, 2844, 1737, $1699,1646,1600,1582,1494,1456,1366,990,927$. HRESI-MS calculated for $\mathrm{C}_{16} \mathrm{H}_{20} \mathrm{O}_{6} \mathrm{Na}+[\mathrm{M}+\mathrm{Na}]+: 331.1152$; found: 331.1168 .

Ethyl 2 - benzoyl - 3 - [2,4 - dimethoxy - 6 - (prop - 2 - en - 1 yloxy)phenyl] - 3 - oxopropanoate (19). To a suspension of $\mathrm{NaH}(60 \%$ in mineral oil, $62 \mathrm{mg}, 1.55 \mathrm{mmol})$ in THF ( $3 \mathrm{~mL})$ was added $\beta$-ketoester 18 
(399 mg, $1.29 \mathrm{mmol})$ in THF (2 mL) at $0{ }^{\circ} \mathrm{C}$ with stirring until evolution of hydrogen had ceased. After this time benzoyl chloride ( $150 \mu \mathrm{L}, 1.29 \mathrm{mmol})$ was added and the reaction warmed to room temperature and stirred overnight. After this time the reaction mixture was poured into $1 \mathrm{M} \mathrm{HCl}(5$ $\mathrm{mL}$ ) on ice and transferred to a separatory funnel. The aqueous phase was extracted with EtOAc (x2) and the combined organic extracts were washed with water and brine, dried over magnesium sulfate, filtered and reduced in vacuo. The crude residue was purified by silica gel chromatography (1:42:3 EtOAc/40-60 Pet. Ether) to provide the title compound as an oil (98 $\mathrm{mg}$, 18\%). ${ }^{1} \mathrm{H}$ NMR (400 MHz, $\mathrm{CDCl}_{3}$ ), $\delta(\mathrm{ppm}): 8.14-8.10(\mathrm{~m}, 2 \mathrm{H}), 7.54(\mathrm{~m}$, $1 \mathrm{H}), 7.45-7.39(\mathrm{~m}, 2 \mathrm{H}), 6.11(\mathrm{~d}, 1 \mathrm{H}, \mathrm{J}=2.1 \mathrm{~Hz}), 6.08(\mathrm{~d}, 1 \mathrm{H}, \mathrm{J}=2.1 \mathrm{~Hz})$, $5.99(\mathrm{~s}, 1 \mathrm{H}), 5.93(\mathrm{~m}, 1 \mathrm{H}), 5.32(\mathrm{~m}, 1 \mathrm{H}), 5.17(\mathrm{~m}, 1 \mathrm{H}), 4.49(\mathrm{~m}, 2 \mathrm{H}), 4.12$ (q, $2 \mathrm{H}, \mathrm{J}=7.2 \mathrm{~Hz}$ ), $3.79(\mathrm{~s}, 3 \mathrm{H}), 3.76(\mathrm{~s}, 3 \mathrm{H}), 1.14(\mathrm{t}, 3 \mathrm{H}, \mathrm{J}=7.2 \mathrm{~Hz}) .{ }^{13} \mathrm{C}$ NMR (100 MHz, CDCl3), $\delta$ (ppm): 164.6, 163.2, 162.4, 159.8, 158.8, 151.9 133.0, 132.7, 130.2, 128.3, 117.6, 112.9, 106.1, 91.9, 90.9, 69.5, 60.0, 56.0, 55.3, 14.1. FTIR (ATR / cm-1): 2980, 1720, 1646, 1604, 1582, 1420, 705. HRESI-MS calculated for $\mathrm{C}_{23} \mathrm{H}_{24} \mathrm{O}_{7} \mathrm{Na}+[\mathrm{M}+\mathrm{Na}]+:$ : 435.1414; found: 435.1415

1 - (2,4 - Dimethoxybenzoyl) - 1H - 1,2,3 - benzotriazole (20). Thionyl chloride (4.82 mL, $66.1 \mathrm{mmol}$ ) was added to a solution of benzotriazole $(23.2 \mathrm{~g}, 203 \mathrm{mmol})$ in DCM (100 mL) with stirring for 30 minutes. To this was added a solution of 2,4-dimethoxybenzoic acid $(9.26 \mathrm{~g}, 50.8 \mathrm{mmol})$ in DCM $(100 \mathrm{~mL})$ dropwise, followed by stirring for $2 \mathrm{~h}$. The precipitate was filtered off and the solvents washed with saturated $\mathrm{NaHCO}_{3}(\mathrm{aq})$ solution $(50 \mathrm{~mL})$, water $(100 \mathrm{~mL})$ and brine $(50 \mathrm{~mL})$, dried and reduced in vacuo. The crude acylbenzotriazole was triturated with $\mathrm{MeOH}$ to provide the tile compound as a solid (10.4 g, 72\%). ${ }^{1} \mathrm{H}$ NMR $\left(400 \mathrm{MHz}, \mathrm{CDCl}_{3}\right), \delta(\mathrm{ppm})$ : $8.35(\mathrm{~d}, 1 \mathrm{H}, \mathrm{J}=8.3 \mathrm{~Hz}), 8.13(\mathrm{~d}, 1 \mathrm{H}, \mathrm{J}=8.3 \mathrm{~Hz}), 7.70-7.63(\mathrm{~m}, 2 \mathrm{H}), 7.52$ (t, $1 \mathrm{H}, \mathrm{J}=7.9 \mathrm{~Hz}), 6.63(\mathrm{dd}, 1 \mathrm{H}, \mathrm{J}=8.5,2.2 \mathrm{~Hz}), 6.57(\mathrm{~d}, 1 \mathrm{H}, \mathrm{J}=2.2 \mathrm{~Hz})$, 3.90 (s, 3H), 3.77 (s, 3H). ${ }^{13} \mathrm{C} \mathrm{NMR}\left(100 \mathrm{MHz}, \mathrm{CDCl}_{3}\right), \delta$ (ppm): 166.1 , 164.6, 160.3, 146.0, 133.0, 131.7, 130.0, 125.9, 120.0, 115.0, 114.4, 105.0, 99.0, 55.8, 55.6. FTIR (ATR / cm-1): 3008, 2967, 2942, 2840, 1706, 1604, $1576,1450,1419,1362,1312,1126,1048,878,807,758$. HRESI-MS calculated for $\mathrm{C}_{15} \mathrm{H}_{13} \mathrm{~N}_{3} \mathrm{O}_{4} \mathrm{Na}+[\mathrm{M}+\mathrm{Na}]+: 306.0849$; found: 306.0855 . MP: $116-119^{\circ} \mathrm{C}$

1 - (2 - Methoxyphenyl) - 3 - [2 - (prop - 2 - en - 1 yloxy)phenyl]propane - 1,3 - dione (28). A solution of 2allyloxyacetophenone $(4.00 \mathrm{~g}, 22.6 \mathrm{mmol})$ in THF $(40 \mathrm{~mL})$ was cooled to $0{ }^{\circ} \mathrm{C}$ followed by the addition of $\mathrm{NaH}$ ( $60 \%$ in mineral oil, $2.27 \mathrm{~g}, 56.7 \mathrm{mmol}$ ) with stirring for 30 minutes. The solution was warmed to room temperature followed by the addition of methyl 2-(methoxy)benzoate $(4.15 \mathrm{~g}, 25.0$ $\mathrm{mmol})$ in THF $(30 \mathrm{~mL})$. The reaction was heated at reflux for 24 hours, cooled to room temperature and acidified with $1 \mathrm{M} \mathrm{HCl}$ solution. The organic layer was separated, and the aqueous phase extracted with EtOAc $(30 \mathrm{~mL})$. The combined organic extracts were washed with water $(30 \mathrm{~mL})$ and brine $(30 \mathrm{~mL})$, dried over magnesium sulfate and concentrated in vacuo. The crude residue was purified by column chromatography (1:42:3 EtOAc/40-60 Pet. Ether) to afford the title compound as an oil (5.8 g, 82\%). ${ }^{1} \mathrm{H}$ NMR (400 MHz, $\mathrm{CDCl}_{3}$ ), $\delta$ (ppm): Enol: 7.91 (dd, $2 \mathrm{H}, \mathrm{J}=7.8,1.8$ $\mathrm{Hz})$, 7.47-7.39 (m, $3 \mathrm{H}), 7.36(\mathrm{~s}, 1 \mathrm{H}), 7.05$ (tdd, $2 \mathrm{H}, \mathrm{J}=7.6,2.7,0.7 \mathrm{~Hz})$, $7.02-6.85(\mathrm{~m}, 4 \mathrm{H}), 6.07(\mathrm{~m}, 1 \mathrm{H}), 5.44(\mathrm{dq}, 1 \mathrm{H}, \mathrm{J}=17.3,1.5 \mathrm{~Hz}), 5.26(\mathrm{dq}$, $1 \mathrm{H}, \mathrm{J}=10.6,1.4 \mathrm{~Hz}), 4.67(\mathrm{dt}, 2 \mathrm{H}, \mathrm{J}=5.0,1.5 \mathrm{~Hz}), 3.89(\mathrm{~s}, 3 \mathrm{H})$. Keto: 7.86 $(\mathrm{m}, 1 \mathrm{H}), 7.47-7.39(\mathrm{~m}, 3 \mathrm{H}), 7.05$ (tdd, $2 \mathrm{H}, \mathrm{J}=7.6,2.7,0.7 \mathrm{~Hz}), 7.02-6.85$ $(\mathrm{m}, 4 \mathrm{H}), 5.89(\mathrm{~m}, 0.3 \mathrm{H}), 5.32(\mathrm{~m}, 0.3 \mathrm{H}), 5.19(\mathrm{~m}, 0.3 \mathrm{H}), 4.64(\mathrm{~s}, 0.5 \mathrm{H})$, $4.54(\mathrm{~m}, 0.5 \mathrm{H}), 3.69$ (s, 0.7H). ${ }^{13} \mathrm{C}$ NMR (125 MHz, CDCl 3 ), $\delta(\mathrm{ppm})$ : Enol:187.2, 187.1, 161.1, 160.0, 135.5, 135.4, 135.3, 133.1, 133.0, 123.6, 123.3, 120.2, 115.8, 114.2, 106.3, 72.2, 62.2, 58.4. Keto: 187.2, 136.9, 136.6, 135.0, 133.7, 133.6, 128.6, 128.1, 123.5, 123.4, 121.0, 115.3, 114.1, 72.0, 57.9. FTIR (ATR / cm-1): 3076, 2940, 2838, 1667, 1599, 1486, 1244, 753. HRESI-MS calculated for $\mathrm{C}_{19} \mathrm{H}_{18} \mathrm{O}_{4} \mathrm{Na}+[\mathrm{M}]+$ : 333.1097 ; found: 333.1120

Methyl (2E) - 4 - [2 - (2 - hydroxyphenyl) - 4 - oxo - 4H - chromen 3 - yl]but - 2 - enoate (33). To a solution of flavone $30(450 \mathrm{mg}, 1.6$ $\mathrm{mmol}$ ) in DCM (3.6 mL) was added phenol $(76 \mathrm{mg}, 0.8 \mathrm{mmol})$, methyl acrylate $(1.5 \mathrm{~mL}, 16 \mathrm{mmol})$ and Grubbs second generation catalyst ( $96 \mathrm{mg}$, $7 \mathrm{~mol} \%)$. The reaction was heated at reflux for 24 hours and the volatiles were removed in vacuo and the crude residue purified by column chromatography (1:4-2:3 EtOAc/40-60 Pet. Ether) to provide the title compound (122 $\mathrm{mg}, 22 \%)$ and recovered starting material $(216 \mathrm{mg}, 48 \%)$. ${ }^{1} \mathrm{H}$ NMR $\left(500 \mathrm{MHz}, \mathrm{CDCl}_{3}\right), \delta(\mathrm{ppm}): 8.15(\mathrm{dd}, 1 \mathrm{H}, \mathrm{J}=8.0,1.5 \mathrm{~Hz}), 7.62$ (ddd, $1 \mathrm{H}, \mathrm{J}=8.4,7.2,1.6 \mathrm{~Hz}), 7.45(\mathrm{~s}, 1 \mathrm{H}), 7.41(\mathrm{~d}, 1 \mathrm{H}, \mathrm{J}=8.4 \mathrm{~Hz}$ ), 7.40 - $7.33(\mathrm{~m}, 2 \mathrm{H}), 7.29(\mathrm{dd}, 1 \mathrm{H}, \mathrm{J}=7.6,1.6 \mathrm{~Hz}), 7.06(\mathrm{~d}, 1 \mathrm{H}, \mathrm{J}=8.2 \mathrm{~Hz}), 7.00$ $(\mathrm{t}, 1 \mathrm{H}, \mathrm{J}=7.5 \mathrm{~Hz}), 6.94(\mathrm{dt}, 1 \mathrm{H}, \mathrm{J}=15.7,6.3 \mathrm{~Hz}), 5.66(\mathrm{dt}, 1 \mathrm{H}, \mathrm{J}=15.7$, $1.4 \mathrm{~Hz}), 3.60(\mathrm{~s}, 3 \mathrm{H}), 3.30$ (dd, $2 \mathrm{H}, \mathrm{J}=6.4,1.4 \mathrm{~Hz}) .{ }^{13} \mathrm{C} \mathrm{NMR}(125 \mathrm{MHz}$, $\left.\mathrm{CDCl}_{3}\right), \delta(\mathrm{ppm}): 180.7,169.9,164.1,159.1,156.6,148.8,136.5,134.9$, 132.6, 128.4, 127.8, 125.4, 124.1, 123.0, 122.5, 122.3, 120.7, 119.7, 54.1, 31.3. FTIR (ATR / cm-1): 3294, 2953, 2950, 1723, 1623, 1613, 1455, 1436 , 984, 759. HRESI-MS calculated for $\mathrm{C}_{20} \mathrm{H}_{16} \mathrm{O}_{5} \mathrm{Na}+[\mathrm{M}]+:$ 359.0896; found: 359.0901

2 - [4 - Oxo - 3 - (prop - 2 - en - 1 - yl) - 4H - chromen - 2 - yl]phenyl acetate (31) To a solution of flavone $\mathbf{3 0}(776 \mathrm{mg}, 2.79 \mathrm{mmol})$ in pyridine $(20 \mathrm{~mL})$ maintained at $0{ }^{\circ} \mathrm{C}$ was added acetic anhydride $(427 \mathrm{mg}, 4.18$ $\mathrm{mmol}$ ). The reaction was warmed to room temperature and stirred until consumption of starting material as indicated by TLC. The reaction was diluted with water and extracted with EtOAc $(20 \mathrm{ml}, \mathrm{x} 2)$. The combined organic extracts were washed with water $(50 \mathrm{~mL})$, brine $(50 \mathrm{~mL})$ and dried over magnesium sulfate, filtered and reduced in vacuo. The crude residue was purified by column chromatography (1:4 - $2: 3 \mathrm{EtOAc} / 40-60$ Pet. Ether) to provide the title compound as a solid ( $800 \mathrm{mg}, 90 \%)$. ${ }^{1} \mathrm{H} \mathrm{NMR}(500 \mathrm{MHz}$, $\left.\mathrm{CDCl}_{3}\right), \delta(\mathrm{ppm}): 8.26(\mathrm{~m}, 1 \mathrm{H}), 7.66(\mathrm{~m}, 1 \mathrm{H}), 7.59-7.52(\mathrm{~m}, 2 \mathrm{H}), 7.44-7.35$ $(\mathrm{m}, 3 \mathrm{H}), 7.28(\mathrm{dd}, 1 \mathrm{H}, \mathrm{J}=8.2,0.8 \mathrm{~Hz}), 5.91(\mathrm{~m}, 1 \mathrm{H}), 4.97(\mathrm{dq}, 1 \mathrm{H}, \mathrm{J}=10.1$, $1.5 \mathrm{~Hz}), 4.91(17.2,1.6 \mathrm{~Hz}), 3.18(\mathrm{~d}, 2 \mathrm{H}, \mathrm{J}=4.5 \mathrm{~Hz}), 2.09(\mathrm{~s}, 3 \mathrm{H}) .{ }^{13} \mathrm{C} \mathrm{NMR}$ (125 MHz, CDCl3), $\delta$ (ppm): 180.4, 171.5, 161.9, 158.9, 150.9, 137.9, 136.3, 134.2, 133.1, 128.8, 128.7, 128.6, 127.6, 126.1, 125.7, 124.1, 120.4, 118.2, 32.5, 23.4. FTIR (ATR/ cm-1): 3079, 2936, 1766. 1648, 1627, 1464, 1380, 759. HRESI-MS calculated for $\mathrm{C}_{20} \mathrm{H}_{16} \mathrm{O}_{4} \mathrm{Na}+[\mathrm{M}]+: 343.0941$; found: 343.0930. MP $112-115^{\circ} \mathrm{C}$.

Methyl (2E) - 4 - \{2 - [2 - (acetyloxy)phenyl] - 4 - oxo - 4H chromen - 3 - yl\}but - 2 - enoate (34). To a solution of flavone 31 (748 $\mathrm{mg}, 2.34 \mathrm{mmol})$, methyl acrylate $(2.0 \mathrm{~g}, 23.3 \mathrm{mmol})$ and phenol $(110 \mathrm{mg}$, $1.17 \mathrm{mmol})$ in DCM $(5 \mathrm{~mL})$ was added Grubbs 2 nd generation catalyst (149 mg, $7.5 \mathrm{~mol} \%$ ). The solution was heated at reflux for 24 hours, before the volatiles were removed in vacuo and the crude residue purified by column chromatography (1:4 - 2:3 EtOAc/40-60 Pet. Ether) to provide the title compound as an oil(680 mg, $77 \%) .{ }^{1} \mathrm{H}$ NMR $\left(500 \mathrm{MHz}, \mathrm{CDCl}_{3}\right), \delta$ (ppm): $8.25(\mathrm{~m}, 1 \mathrm{H}), 7.68(\mathrm{~m}, 1 \mathrm{H}), 7.57(\mathrm{~m}, 1 \mathrm{H}), 7.46(\mathrm{td}, 1 \mathrm{H}, \mathrm{J}=7.7,1.6$ 
$\mathrm{Hz}), 7.43-7.40(\mathrm{~m}, 2 \mathrm{H}), 7.38$ (td, $1 \mathrm{H}, \mathrm{J}=7.6,1.1 \mathrm{~Hz}), 7.28(\mathrm{dd}, 1 \mathrm{H}, \mathrm{J}=$ 8.3, $0.8 \mathrm{~Hz}), 6.99(\mathrm{dt}, 1 \mathrm{H}, \mathrm{J}=15.7,6.3 \mathrm{~Hz}), 5.70(\mathrm{dt}, 1 \mathrm{H}, \mathrm{J}=15.7,1.6 \mathrm{~Hz})$, $3.67(\mathrm{~s}, 3 \mathrm{H}), 3.31(\mathrm{~s}, 2 \mathrm{H}), 2.09(\mathrm{~s}, 3 \mathrm{H}) .{ }^{13} \mathrm{C} \mathrm{NMR}\left(125 \mathrm{MHz}, \mathrm{CDCl}_{3}\right), \delta$ (ppm): 180.0, 171.4, 169.4, 162.5, 158.9, 150.9, 148.3, 136.6, 134.5, 132.8 128.8, 128.6, 128.4, 127.9, 126.2, 125.5, 124.5, 122.4, 120.5, 54.1, 31.1, 23.4. FTIR (ATR/ cm-1): 2954, 1769, 1721, 1640, 1467, 1387, 1275, 1188 , 943, 762. HRESI-MS calculated for $\mathrm{C}_{22} \mathrm{H}_{18} \mathrm{O}_{6} \mathrm{Na}+[\mathrm{M}]+:$ 401.0996; found: 401.0967

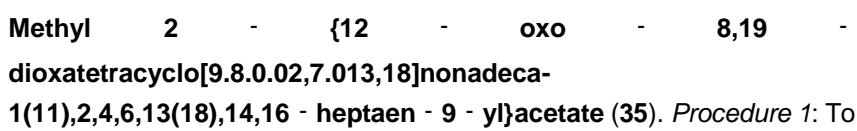
a solution of the hydroxyflavone $33(27.0 \mathrm{mg}, 0.080 \mathrm{mmol})$ in anhydrous $\mathrm{MeOH}(1 \mathrm{~mL})$ was added sodium acetate $(7.9 \mathrm{mg}, 0.096 \mathrm{mmol})$, and the reaction was heated at reflux. Upon consumption of starting material as indicated by TLC the reaction was cooled, diluted with water and extracted with EtOAc (x2). The combined organic extracts were washed with water and brine, dried over magnesium sulfate and reduced in vacuo. The crude residue was purified by column chromatography (1:4 EtOAc/40-60 Pet. ether) to provide the title compound as a solid (22 $\mathrm{mg}, 81 \%)$. Procedure 2: To a solution of the acetoxyflavone $\mathbf{3 4}(510 \mathrm{mg}, 1.35 \mathrm{mmol})$ in anhydrous $\mathrm{MeOH}(20 \mathrm{~mL})$ was added sodium acetate $(293 \mathrm{mg}, 3.6 \mathrm{mmol})$, and the reaction was heated at reflux. Upon consumption of starting material as indicated by TLC the reaction was cooled, diluted with water and extracted with EtOAc (x2). The combined organic extracts were washed with water and brine, dried over magnesium sulfate and reduced in vacuo. The crude residue was purified by column chromatography (1:4-2:3 EtOAc/40-60 Pet. ether) to provide the title compound as a solid (398 mg, 88\%). ${ }^{1} \mathrm{H}$ NMR (400 MHz, $\mathrm{CDCl}_{3}$ ), $\delta$ (ppm): 8.25 (d, $1 \mathrm{H}, \mathrm{J}=8.0 \mathrm{~Hz}$ ), 7.90 (d, $1 \mathrm{H}, \mathrm{J}=8.90$ $\mathrm{Hz}), 7.69(\mathrm{t}, 1 \mathrm{H}, \mathrm{J}=7.8 \mathrm{~Hz}), 7.53(\mathrm{~d}, 1 \mathrm{H}, \mathrm{J}=8.5 \mathrm{~Hz}), 7.47(\mathrm{t}, 1 \mathrm{H}, \mathrm{J}=7.7$ $\mathrm{Hz}), 7.42(\mathrm{t}, 1 \mathrm{H}, \mathrm{J}=7.7 \mathrm{~Hz}), 7.28(\mathrm{~m}, 1 \mathrm{H}), 7.15(\mathrm{~d}, 1 \mathrm{H}, \mathrm{J}=8.1 \mathrm{~Hz}), 5.08$ (sep, $1 \mathrm{H}, \mathrm{J}=4.2 \mathrm{~Hz}$ ), $3.76(\mathrm{~s}, 3 \mathrm{H}), 3.16(\mathrm{dd}, 1 \mathrm{H}, \mathrm{J}=15.6,4.0 \mathrm{~Hz}), 2.84$ $(\mathrm{dd}, 1 \mathrm{H}, \mathrm{J}=15.6,9.0 \mathrm{~Hz}), 2.74-2.66(\mathrm{~m}, 2 \mathrm{H}) .{ }^{13} \mathrm{C} \mathrm{NMR}\left(100 \mathrm{MHz}, \mathrm{CDCl}_{3}\right)$, $\delta$ (ppm): 176.9, 170.9, 159.0, 156.2, 155.8, 133.6, 132.4, 128.3, 126.0, 125.0, 123.9, 123.5, 122.6, 118.5, 118.0, 84.4, 51.9, 40.4, 28.2. FTIR (ATR / cm-1): 2926, 2853, 1766, 1733, 1628, 1607, 1574, 1467, 1378, 1160, 753 HRESI-MS calculated for $\mathrm{C}_{20} \mathrm{H}_{16} \mathrm{O}_{5} \mathrm{Na}+[\mathrm{M}+\mathrm{Na}]+$ : 359.0890; found: 359.0897. MP $128-130^{\circ} \mathrm{C}$.

\section{5,14,16 - Trimethoxy - 9 - methyl - 8,19 -} dioxatetracyclo[9.8.0.02,7.013,18]nonadeca - 1(11),2,4,6,13,15,17 heptaen - 12 - one (40a) and 14 - Hydroxy - 5,16 - dimethoxy - 9 methyl - 8,19 - dioxatetracyclo[9.8.0.02,7.013,18]nonadeca $1(11), 2,4,6,13,15,17$ - heptaen - 12 - one (40b). A solution of the flavone 39 (18 mg, $0.047 \mathrm{mmol})$ and $\mathrm{Nal}(22 \mathrm{mg}, 0.0633 \mathrm{mmol})$ in $48 \% \mathrm{HBr}(200$ $\mu \mathrm{L}$ ) was heated at $100{ }^{\circ} \mathrm{C}$ in a sealed kimax tube for 2 hours. After this time, the reaction was diluted with EtOAc and washed with water. The aqueous phase was back-extracted with EtOAc $(\times 3)$ and the combined organic extracts were washed with water and brine, dried over magnesium sulfate and reduced in vacuo. Column chromatograpy (1:4-3:2 EtOAc/4060 Pet. Ether) provided the products 40 a as an oil $(2 \mathrm{mg}, 12 \%) .{ }^{1} \mathrm{H}$ NMR $\left(500 \mathrm{MHz}, \mathrm{CDCl}_{3}\right), \delta(\mathrm{ppm}): 7.84(\mathrm{~d}, 1 \mathrm{H}, \mathrm{J}=8.9 \mathrm{~Hz}), 6.76$ (dd, $1 \mathrm{H}, \mathrm{J}=8.9$, $2.6 \mathrm{~Hz}), 6.62(\mathrm{~d}, 1 \mathrm{H}, \mathrm{J}=2.6 \mathrm{~Hz}), 6.51(\mathrm{~d}, 1 \mathrm{H}, \mathrm{J}=2.3 \mathrm{~Hz}), 6.36(\mathrm{~d}, 1 \mathrm{H}, \mathrm{J}=$ $2.3 \mathrm{~Hz}), 4.64(\mathrm{~m}, 1 \mathrm{H}), 3.95(\mathrm{~s}, 3 \mathrm{H}), 3.90(\mathrm{~s}, 3 \mathrm{H}), 3.85(\mathrm{~s}, 3 \mathrm{H}), 3.11(\mathrm{dd}, 1 \mathrm{H}$, $\mathrm{J}=16.0,3.1 \mathrm{~Hz}), 2.65(\mathrm{dd}, 1 \mathrm{H}, \mathrm{J}=16,7.8 \mathrm{~Hz}), 1.46(\mathrm{~d}, 3 \mathrm{H}, \mathrm{J}=6.3 \mathrm{~Hz}$ ). 13C NMR (125 MHz, $\left.\mathrm{CDCl}_{3}\right)$, $\delta(\mathrm{ppm}): 178.7,166.5,165.2,163.6,162.3$,
161.1, 158.7, 131.8, 121.6, 119.2, 112.8, 110.6, 109.5, 98.5, 95.1, 85.5, 59.0, 58.1, 33.0, 24.3. FTIR (ATR / cm-1): 2922, 2853, 1737, 1601, 1569, $1492,1458,1425,1359,1233,1204,1164,1143,819$. HRESI-MS calculated for $\mathrm{C}_{21} \mathrm{H}_{20} \mathrm{O} 6 \mathrm{Na}+[\mathrm{M}+\mathrm{Na}]+:$ 391.1152; found: 391.1156. Further elution provided $40 \mathrm{~b}$ as an oil: ${ }^{1} \mathrm{H} \mathrm{NMR}\left(500 \mathrm{MHz}, \mathrm{CDCl}_{3}\right), \delta$ (ppm): 7.84 $(\mathrm{d}, 1 \mathrm{H}, \mathrm{J}=8.9 \mathrm{~Hz}), 6.78(\mathrm{dd}, 1 \mathrm{H}, \mathrm{J}=8.9,2.6 \mathrm{~Hz}), 6.63(\mathrm{~d}, 1 \mathrm{H}, \mathrm{J}=2.6 \mathrm{~Hz})$, $6.44(\mathrm{~d}, 1 \mathrm{H}, \mathrm{J}=2.3 \mathrm{~Hz}), 6.36(\mathrm{~d}, 1 \mathrm{H}, \mathrm{J}=2.3 \mathrm{~Hz}), 4.67(\mathrm{~m}, 1 \mathrm{H}), 3.88(\mathrm{~s}$, $3 \mathrm{H}), 3.86(\mathrm{~s}, 3 \mathrm{H}), 3.10(\mathrm{dd}, 1 \mathrm{H}, \mathrm{J}=15.9,3.2 \mathrm{~Hz}), 2.59(\mathrm{dd}, 1 \mathrm{H}, \mathrm{J}=15.9$, $8.1 \mathrm{~Hz}), 1.48(\mathrm{~d}, 3 \mathrm{H}, \mathrm{J}=6.3 \mathrm{~Hz}) .{ }^{13} \mathrm{C} \mathrm{NMR}\left(125 \mathrm{MHz}, \mathrm{CDCl}_{3}\right), \delta(\mathrm{ppm})$ : 183.5, 168.0, 165.8, 164.7, 162.0, 161.2, 160.3, 132.2, 119.1, 119.0, 113.1, 109.7, 107.2, 100.5, 94.7, 85.4, 58.4, 58.2, 32.4, 24.2. FTIR (ATR/ cm-1): 2923, 2844, 1659, 1599, 1498, 1454, 1213, 1158, 1117, 1028, 807. HRESI-MS calculated for $\mathrm{C}_{20} \mathrm{H}_{18} \mathrm{O}{ }_{6} \mathrm{Na}+[\mathrm{M}+\mathrm{Na}]+:$ : 377.0996; found: 377.0990 .

Keywords: flavone $\cdot$ natural product $\bullet$ total synthesis $\cdot$ oxepine• oxidative cyclization

[1] A. T. Mbaveng, L. P. Sandjo, S. B. Tankeo, A. R. Ndifor, A. Pantaleon, B. T. Nagdjui, V. Kuete, SpringerPlus 2015, 4, 823.

[2] I. Musthapa, L. D. Juliawaty, Y. M. Syah, E. H. Hakim, J. Latip, E. L. Ghisalberti, Arch. Pharmacal Res. 2009, 32, 191.

[3] H. M. Cidade, M. S. Nacimento, M. M. M. Pinto, A. Kijjoa, A. M. S. Silva, W. Herz, Planta Med. 2001, 67, 867-870.

[4] a) A. D. Pendse, R. Pendse, A. V. R. Rao, K. Venkataraman, Indian J. Chem., Sect. B 1976, 14B, 69-72; b) A. V. R. Rao, M. Varadan, K. Venkataraman, Indian J. Chem. 1973, 11, 298-299.

[5] a) U. K. Mallik, M. M. Saha, A. K. Mallik, Indian J. Chem., Sect. B 1989 28B, 970-972; b) O. V. Singh, M. Muthukrishnan, G. Raj, Synth. Commun. 2005, 35, 2723-2728; c) Z. Du, H. Ng, K. Zhang, H. Zeng, J. Wang, Org. Biomol. Chem. 2011, 9, 6930-6933; d) D. Yoshii, X. Jin, T. Yatabe, J.-y. Hasegawa, K. Yamaguchi, N. Mizuno, Chem. Commun. (Cambridge, U. K.) 2016, 52, 14314-14317.

[6] C. G. Shanker, B. V. Mallaiah, G. Srimannarayana, Synthesis 1983, 310311.

[7] T. Nomura, T. Fukai, S. Yamada, M. Katayanagi, Chem. Pharm. Bull 1978, 26, 1431-1436.

[8] S. A. French, M. R. Clark, R. J. Smith, T. Brind, B. C. Hawkins, Tetrahedron 2018, 74, 5340-5350.

[9] R. J. Smith, R. L. Bower, S. A. Ferguson, R. J. Rosengren, G. M. Cook, B. C. Hawkins, Eur. J. Org. Chem. 2019, 2019, 1571-1573.

[10] R. J. Smith, D. Nhu, M. R. Clark, S. Gai, N. T. Lucas, B. C. Hawkins, J. Org. Chem. 2017, 82, 5317-5327.

[11] J. Tsuji, Synthesis 1984, 1984, 369-384.

[12] B. W. Michel, L. D. Steffens, M. S. Sigman, J. Am. Chem. Soc. 2011, 133 , 8317-8325.

[13] a) D. A. Chaudhari, R. A. Fernandes, J. Org. Chem. 2016, 81, 21132121; b) D. K. Mohapatra, P. Dasari, H. Rahaman, R. Pal, Tetrahedron Lett. 2009, 50, 6276-6279.

[14] a) C. N. Cornell, M. S. Sigman, J. Am. Chem. Soc. 2005, 127, 27962797; b) C. N. Cornell, M. S. Sigman, Org. Lett. 2006, 8, 4117-4120.

[15] a) B. D. M. Cunningham, P. R. Lowe, M. D. Threadgill, J. Chem. Soc., Perkin Trans. 2 1989, 1275-1283; b) U. Anthoni, C. Christophersen, P. H. Nielsen, Acta Chem. Scand. 1995, 49, 357-360; c) T. Patonay, D. Molnar, Z. Muranyi, Bull. Soc. Chim. Fr. 1995, 132, 233-242; d) R. S. G. R. Seixas, D. C. G. A. Pinto, A. M. S. Silva, J. A. S. Cavaleiro, Aust. J. Chem. 2008, 61, 718-724; e) K. Hu, W. Wang, J. Ren, Tianran Chanwu Yanjiu Yu Kaifa 2010, 22, 1028-1030.

[16] D. Lim, Fang, G. Zhou, D. M. Coltart, Org. Lett. 2007, 9, 4139-4142.

[17] Z. Wang, L. Zhu, F. Yin, Z. Su, Z. Li, C. Li, J. Am. Chem. Soc. 2012, 134, 4258-4263.

[18] B. E. Swaney, S. Gai, M. R. Clark, B. C. Hawkins, Chem. Asian J. 2019, 14, 1102-1105. 
WILEY-VCH

FULL PAPER

[19] a) Y. Tu, Z.-X. Wang, Y. Shi, J. Am. Chem. Soc. 1996, 118, 9806-9807; b) T. Katsuki, K. B. Sharpless, J. Am. Chem. Soc. 1980, 102, 5974-5976. 
Entry for the Table of Contents (Please choose one layout)

Layout 1:

\section{FULL PAPER}

Text for Table of Contents (about 350 characters)

*one or two words that highlight the emphasis of the paper or the field of the study

\section{Key Topic*}

Author(s), Corresponding Author(s)*

Page No. - Page No.

Title

((Insert TOC Graphic here: max. width: $5.5 \mathrm{~cm}$; max. height: $5.0 \mathrm{~cm}$; NOTE: the final letter height should not be less than $2 \mathrm{~mm}$.))

\section{Layout 2:}

\section{FULL PAPER}

A full account of our original synthetic strategies to access oxyisocyclointegrin along with further details of our ultimately successful are described.<smiles>C=CCOc1cc(OC)cc(OC)c1C(C)=O</smiles>

15

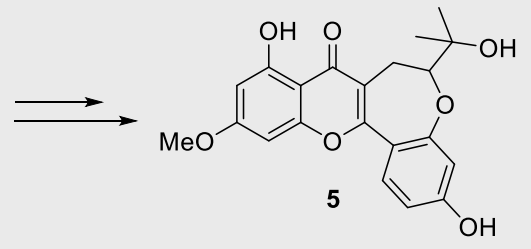

\section{Total Synthesis*}

Robert J. Smith*, Bill C. Hawkins*

Page No. - Page No.

Synthetic Strategies Towards the Synthesis of Oxyisocyclointegrin 